\title{
Asymmetrical Hybridities: Youths at Francophone Games in Canada'
}

\author{
Christine Dallaire \\ Claude Denis
}

\begin{abstract}
The purpose of this ethnographic comparative study of the Jeux de l'Acadie, the Jeux franco-ontariens and the Alberta Francophone Games is to explore further how minority youth identities are produced and manifested in Canada's francophonies. Through interviews, drawings and questionnaires adolescents express and give meaning to their francophoneness in the context of the Games. The analysis reveals that francophone identities are reproduced as a component of hybrid identities. This hybridity refers to youths' integration of once distinct francophone and anglophone cultural identities into a "hybrid" identity. This paper examines the different configurations of these hybrid cultural and linguistic identities, where some youths spontaneously and mostly live in French but insist on their hybridity, while other youths perform predominantly as anglophones but remain attached to their francophoneness. Indeed, Acadian youths primarily perform a singular francophone identity while Franco-Ontarian and Alberta francophone youths manifest a rather complex and asymmetrical mélange of francophoneness and anglophoneness.
\end{abstract}

Résumé: Le but de cette ethnographie comparative des Jeux de l'Acadie, des Jeux franco-ontariens et des Jeux francophones de l'Alberta est de mieux comprendre comment les jeunes minoritaires des francophonies canadiennes produisent et manifestent leur identité. À travers des entrevues, des dessins et des questionnaires, les adolescents expriment et donnent un sens à leur francité dans le contexte des Jeux. L'analyse révèle que les identités francophones sont reproduites en tant que composante d'identités hybrides. Cette hybridité renvoie à l'intégration par les jeunes d'identités culturelles auparavant distinctes, les identités francophone et anglophone, en une nouvelle identité "hybride". Cet article examine les différentes configurations de ces identités culturelles et

1. A preliminary version of this paper was presented in the context of the University of Ottawa Research Centre for Sport in Canadian Society workshop series. We are indebted to Robert Hollands and to other workshop participants for their thought-provoking suggestions. We are also grateful to the anonymous reviewers for their comments and suggestions. 
linguistiques hybrides qui mènent certains jeunes à vivre spontanément et surtout en français mais à insister sur leur hybridité tandis que d'autres jeunes vivent surtout en anglais mais demeurent attachés à leur francité. En effet, les jeunes acadiens manifestent une identité francophone monolithique alors que les jeunes franco-ontariens et franco-albertains reproduisent un mélange complexe et asymétrique, combinant francité et identité anglophone.

\section{Introduction}

It is a perennial feature of life in Canada and of Canadian social science practice to examine the somewhat uneasy yet peaceful cohabitation of Frenchand English-language communities in this wealthy, democratic, advanced capitalist country. The relationship between mostly francophone Quebec and the rest of Canada, which is mostly anglophone, is one aspect of this story. The place of minority language communities among the two majorities is the story's other key aspect, with the Canadian government's official languages policy playing a dominant role.

The great challenge for francophone minorities, over the many generations of their existence, has been to fight off what used to be called their assimilation by the majority. As "assimilation" acquired a rather pejorative connotation among those so challenged, the language of research moved toward the more neutral "linguistic transfer." In both cases, however, the idea has been that culturally vulnerable and unstable identities were undermined and ground down by a strong, stable majority identity. Current trends in scholarship, in the context of a globalization marked by the spread of American popular culture, have been making this stance difficult to sustain: internationally, it has been getting clear for a number of years that the identities of dominant groups are themselves unstable, changing, interacting and mixing with other identities. The impact of this realization, however, has not been felt fully in the study of Canada's francophone minorities. Yet, as these minorities differ in many respects, while they also share basic characteristics grounded in the life of the Canadian state, they offer an ideal terrain for the comparative analysis of the dynamic trends in identity change.

In Canada, francophones have generally been defined on the basis of having French as mother tongue. So defined by the 2001 census, they represent a minority of 6.8 million, or 22.9 percent of the total Canadian population (Statistics Canada, 2002). The greatest number of francophones (5.8 million or 85.5 percent) resides in Quebec, where they represent the majority (81.4 percent) of the population. The remaining 980,300 francophones (14.5 percent) constitute "francophone communities" and live as minorities in the other provinces of Canada where they are subjected, to varying degrees, to the hegemonic influences of English-language popular culture and media. To ensure their continued existence and development, these minorities must therefore develop explicit strategies, on an ongoing basis, to sustain 
"francophoneness"2 among their younger generations - that is to say they need to ensure that the greatest number possible of children from francophone families will retain this character of being francophone.

The Jeux de l'Acadie (JA), the Jeux franco-ontariens (JFO) and the Alberta Francophone Games (AFG) are such attempts at community development and are thus germane empirical sites to study youths' francophoneness. The comparative ethnography of these youth games thus provides a rich empirical context to explore further the production and manifestation of minority youth identities. ${ }^{3}$ In Acadia/New Brunswick, Ontario and Alberta, these identities are produced not only as hybrids, but as hybrid forms distinct from one another as a function of different social power balances in the three provinces. Indeed, in this multi-provincial context, it becomes very clear that the production of hybridity should be accounted for not by some kind of soft, consensual, postmodern social play, but rather by the workings of power relations in society. Thus, the comparative analysis of the three games allows for a glimpse at the concrete ways in which hybridity is modulated through the specific context that defines a particular minority community.

The purpose of this paper, then, is to examine how francophoneness is produced as a component of hybrid identities, where youths integrate distinct francophone and anglophone subjectivities. The analysis, fed by interviews, drawings and questionnaires, focuses on the configuration of these hybrid identities, wherein some minority communities youths perform predominantly as anglophones but remain attached to a claimed francophoneness, while in other communities, youths claiming a hybrid identity appear to live predominantly as francophones. Indeed, the use of three data collection techniques allowed adolescents at the three games to express and give meaning to their francophone identity. Thirty-minute interviews were conducted with 39

2. Francophoneness refers to the distinctive features and character of the practice of French language and of the cultures associated to French language in Canada. It is of course an attribute produced in discourse and not a "natural" or "essential" character that defines francophone identity. We use the concept "francophone" in a very broad manner to refer to all types of identities associated to francophoneness as well as affiliations individuals may develop towards the socially constructed French-speaking communities in Canada. It thus includes such labels as Acadian, Franco-Albertan, Franco-Ontarian, French Canadian, francophone and bilingual. In Butler's (1990) terms, we attempt to open it and consider all possible meanings. Yet, while we seek to broaden the meaning of francophoneness, our research shows how members of francophone communities produce definitions that limit and restrict it. Indeed, there are different versions defining who is a "true" francophone (Dallaire and Denis, 2000).

3. This research project is financially supported by the Social Science and Humanities Research Council of Canada. The comparison draws on the 1996 and 1997 ethnographic data analysed for a previous study of the AFG as well as ethnographic data collected at the 2001 JFO and 2001 JA. 
participants (28 girls and 11 boys) at the 1997 AFG. At the $2001 \mathrm{JA}, 36$ group interviews were conducted with 175 participants (104 girls and 71 boys). And during the $2001 \mathrm{JFO}, 29$ group interviews were conducted with 107 participants (59 girls and 48 boys). Most respondents were interviewed in groups, but individual interviews were conducted with some youths. Respondents were invited to discuss the following: a) the Games; b) how they conceived of francophone identity and community; and c) how they conceived of their own identity. After the group interviews, youths were asked to draw what they viewed as francophone identity or community, or their own identity. Most respondents drew a sketch, but some chose to instead write a statement. A total of 26 drawings were collected at the 1997 AFG, 112 drawings at the 2001 JFO and 181 drawings at the $2001 \mathrm{JA}$. In addition, short-answer questionnaires were administered at the three Games to collect demographic data from participants. Questions also dealt with francophone identity, linguistic practices and involvement in community activities. The response rates from participants were high: 93 percent at the 1996 AFG, 91 percent at the 1997 AFG, 77 percent at the $2001 \mathrm{JFO}$ and 78 percent at the $2001 \mathrm{JA}$. Together, these qualitative and quantitative data provide a more thorough account of how youths make sense of who they are and how, or to what extent, they perform as francophones.

\section{Discourse, hybridity and francophone identities}

Students of Canadian francophone youths' identity have noted the increasing use of English in their everyday lives and the increasing frequency of "bilingualism" as a dimension of youth identity. But while these scholars acknowledge that youths choose to identify as "bilinguals", most have disqualified this as a form of identity, preferring to see it as a marker of deepening assimilation. ${ }^{4}$ Furthermore, francophone studies have not yet examined these new identities as a merging of both francophoneness and anglophoneness, much less as an unequal merging, which is what we propose to do here. We thus turned to cultural studies and the concept of hybridity, drawing predominantly on Pieterse's work $(1995,1997,2001)$, to better understand minority francophone youth identities and their distinctiveness from other manifestations of francophoneness.

The concept of hybridity, in the general context of Foucaldian discourse analysis, has provided the main set of salient ideas that inform our analysis, as it allows a focus on the influence of youths' varied cultural experiences and the

4. The recent ethnographic work of Gérin-Lajoie (2003) is a notable exception. For a review of the literature on francophone youth identities, see Dallaire and Roma (2003). 
discursive environment in which they decide who they are and who they will be. The other set of ideas, which we use more loosely, stems from social movement research and what has been called the power-resource model, a variation of resource mobilization theory first developed in research that sought to account for the varying degrees of success of social-democratic political parties in western countries. We begin with the discussion of hybridity, and will turn to power resources in the next section.

In order to think of identity as having the degree of dynamism that we find expressed among young francophones, it is helpful to conceptualize it as a performance, along the lines that Judith Butler (1990, 1992, 1993) has developed in her feminist/queer adaptation of Foucault's discourse analysis. One becomes a francophone by "doing" the francophone. Identity, then, is a performance constituted by discursive practices, which are generated through the "reiterative power of discourse to produce the phenomena that it regulates and constrains" (1993: 2). In this sense, any identity that is effectively and regularly performed is, automatically, a disciplined identity. However, because identity is a repeated performance, it is also - to varying degrees inherently unstable, open to contest and resistance.

Being unstable, identity will incorporate components that may appear to be alternative, mutually exclusive features of a particular discursive formation. Thus, to a question such as "Are you French or English?", one might answer sensibly "Yes." This is where the concept of hybridity becomes valuable. It refers to the transgression of socially constructed cultural boundaries and to the cross-border experience. ${ }^{5}$ Indeed, in response to the current anti-hybridity backlash (see Anthias, 2001; Friedman, 1997, 1999), Pieterse (2001) provides a compelling argument for the salience of this concept as it problematizes essentialized boundaries. The author $(1995,2001)$ notes that hybridity is based on the assumption of difference between cultures, while also pointing, perhaps paradoxically, to the similarity between them, because they can be merged. The concept therefore underlines simultaneously the blending of cultures and their separateness. It is important to stress, however, that hybridity does not imply the merging and interaction of two stable - much less essential or primordial — cultures or identities (Bhabha, 1994; Pieterse, 2001; Papastergiadis, 2000; Young, 1995). In this research, we use the concept of hybridity to refer specifically to the intersection and transformation of two relatively

5. For instance, this concept has been used to theorize cultural identities at the intersection of the global and the local (Kraidy, 1999; Pieterse, 1994, 1995, 1997), modernity and tradition (Garcia Canclini, 1995) and the colonial and the colonized (Bhabha, 1994; Young, 1995). Studies on youth identities (Butcher and Thomas, 2002; Kraidy, 1999; Noble, Poynting and Tabar, 1999) and on ethnicity (Meerwald, 2001; Romberg, 1996; Slabbert and Finlayson, 2000) have also drawn on this concept to analyze diverse ethnic and linguistic border-crossing experiences. 
(un)stable identities into a new one, also (un)stable. Thus, hybrid identities are heterogeneous and discontinuous.

It is through performing as a francophone that one's francophoneness is "established, instituted, circulated and confirmed" (Butler, 1991: 18). When identity is thought of as a performance, one can say that disciplined francophone youths will perform the practices that define and produce francophoneness discursively. But defining "francophone discourse" is not as straightforward as it might seem. This is because such definitions are produced socially, in ways that express the complexity of social intercourse rather than the lexically regulated neatness of dictionary definitions.

The analysis of the production of francophone identity at the AFG revealed that the concept of francophoneness was contested and unstable, as a result of competition between two conflicting francophone discourses (Dallaire and Denis, 2000). The instability of francophoneness in the Alberta francophone community - more on this below - certainly contributed to the circulation and reproduction of Canadian discourses and of sport discourses so as to contest the francophoneness of the Games. At its simplest, the tension within the francophone discursive formation is between a linguistic discourse establishing the francophone as one who speaks French and a cultural discourse that defines the francophone as a French speaker who participates in a particular history and culture. AFG participants reproduced both the linguistic and the cultural francophone discourses circulating at the Games and articulated them in ways that reproduced the uncertainty of francophone identity (Dallaire, 2001).

Francophone discourses are also competing with anglophone discourses over youths' subjectivity. Indeed, francophone youths take on subject positions in both francophone and anglophone discourses, thus producing hybrid identities. ${ }^{6}$ Hybridity then designates the mixing of distinctive, but not fixed, cultural and linguistic identities into a new, mixed identity. AFG organizers, however, did manage to produce themselves as closer to singular francophones than to hybrids in this fraught discursive context (Dallaire, 1999). Indeed, what is significant about organizers' articulation of francophone discourses at the AFG is that while they produced contested definitions of francophoneness that shifted between linguistic and cultural truths, the predominance of their own francophone identities was never in doubt or at risk. Organizers repeatedly and routinely performed the most basic francophone practice: they spoke French. Their identity ambivalence was between two versions of francophoneness, as opposed to the tension between francophoneness and anglophoneness that

6. See Dallaire (2003a) for a detailed analysis of the different manifestations of francophone youths' hybrid identities at the three Games. 
characterizes participants' identities. While they were exposed and subjected to a variety of other identity discourses and while they did participate in the larger Canadian society, organizers predominantly constituted themselves as francophones. Thus, while the instability of francophone discourses can play a role in undermining the francophone component of hybrid identities by allowing the articulation of other identity discourses, it does not necessarily lead to a weakened francophone identity.

\section{Social power, the communities and the games}

Nothing is ambiguous, in broad outline, in the relationship between the differing configurations of hybridity at the three games, on the one hand, and the strength of the corresponding francophone communities, on the other. Of the three francophone communities that host the games considered here, Alberta's is the weakest, New Brunswick's Acadian community is the strongest and Ontario's is between the other two. Correspondingly, the youths at the JA performed their hybridity with the strongest francophone component, the AFG youths with the weakest, and the Ontario francophones were somewhere in between.

It is not our ambition to quantify the relationship between community strength and youth performance of identity, and the differences between communities. Rather, we merely seek to sketch the direction of the relationship, so as to highlight the part that social power plays in the patterning of hybridity. This is where the basic ideas of resource mobilization theory, and in particular the power-resources model (PRM), come into play. In evaluating the potential of social movements to attain their goals, the PRM focuses on four types of resources from which they may draw: the size of the population within which they function, the money they can raise, their degree of institutionalisation, and their leadership.

For the purpose of this brief overview, issues of population size and of institutionalisation are most relevant. Money, in this case, is a direct function of population size - all the more so as all three communities can draw on the resources of the federal government on the basis of the same per capita formulae. In other words, the AFG have a smaller budget than the JA because there are fewer francophones in Alberta than in Acadia/New Brunswick. Looking at budgets independently would merely be an indirect commentary on population size, and the vagaries of leadership do not provide the kind of stable influence that would help us grasp the long-term making of hybrid identities.

There are many more Ontario francophones than there are Acadians. Francophones account for only a small fraction of Ontario's population, however, and they are spread out over a large territory. Acadians, on the other hand, are fully one-third of New Brunswick's population and they occupy a 
small territory. Albertans, meanwhile, are few in numbers and dispersed over the provincial territory. Intergenerational outcomes of this situation include larger numbers of intercultural (ie "exogamous") marriages and linguistic transfers in Alberta than in Ontario than in Acadia/New Brunswick.

The institutional networks of francophone communities are all proportionately supported by the Canadian government, but unevenly so by relevant provincial governments, as the electoral weight of francophones varies greatly between provinces. Acadia's is the longest established and most developed in relation to the community's needs. Ontario's is also extensive, if less comprehensive. Alberta's francophone network lags far behind. Now, from a large, concentrated population with a strong institutional network, one might expect identities that, although hybrid, display a high degree of communal coherence. Again, Ontario is in between.

\section{Acadia/New Brunswick and the Jeux de l'Acadie}

French settlement in the Maritime Provinces of New Brunswick, Nova Scotia and Prince Edward Island dates back to 1604 and is referred to as l'Acadie. Its history is dramatically marked by the deportation of Acadians between 1755 and 1762, a devastating event that contributes persistently to the construction of the Acadian identity (LeBlanc, 1999). Today, the Acadian community is partitioned in provincial communities but, with its 239,400 francophones mostly concentrated in the region known as the Acadian Peninsula, the New Brunswick Acadian community represents 85.3 percent of the total Maritime Acadian community. In relative terms, it is also the strongest francophone minority at the provincial level, with 32.9 percent of the total New Brunswick population (Statistics Canada, 2002). For the purposes of this article's analysis, only New Brunswick's Acadian community will be considered, as it contributes such a disproportionate share of Acadia's strength.

In the Acadian Peninsula, the region where Acadians are in high numbers and represent a large proportion of the population, the degree of "institutional completeness" (Breton, 1964, 1991) is relatively high. Acadians get services in French from institutions that they manage (as opposed to institutions managed and defined by the anglophone majority): an autonomous school system, community colleges, Université de Moncton (created in 1963) with satellite campuses outside Moncton, hospitals, financial institutions, parishes, an extensive network of associations (for women, youths, various professionals, etc.), press (the daily l'Acadie Nouvelle, which reaches 20,000 readers, and seven weekly papers), electronic media including community radio stations, and arts institutions (Allaire, 1999; Commissioner of Official Languages, 1997).

At the end of the 1960s, New Brunswick elected its first Acadian premier, it adopted official bilingualism (1968) and a bill on the equality of the two 
linguistic communities (1981) that was eventually integrated in the Canadian Constitution (1993). An Acadian political party was even created in the early 1970s, with the goal of creating an Acadian province (Allaire, 1999).

In short, New Brunswick Acadians benefit from a network of welldeveloped institutions active in various sectors of daily social life. The Jeux de l'Acadie (JA), the most established and longest running annual francophone minority Games in Canada, are one such strong institution. First held in 1978, this large multi-sport event modelled after the Olympic Games is organized as a two-tiered competition, with the JA finals drawing over one thousand 10- to 17-year-old athletes from six New Brunswick delegations in addition to one delegation each from Nova Scotia and Prince Edward Island. Staging the finals also means mobilizing about 1,200 to 1,500 volunteers.

Between 1979 and 2001, more than 68,000 youths have participated in the regional contests with over 19,000 of them competing in the finals (Société des Jeux de l'Acadie, 2002). Allain (1996) estimates that over 55,000 youths and 52,000 volunteers took part in the Jeux de l'Acadie between 1979 and the early 1990s. These Games not only comprise regional and final contests, but also include a youth leadership program called the Académie Jeunesse, a quarterly newsletter, La Charette, and a monthly bulletin, La P'tite Charette, full-time employees, a fundraising division called Fondation des Jeux de l'Acadie Inc., and more.

New Brunswick youths account for more than 75 percent of participants at the Games and of respondents to our questionnaire. Taking this fact in consideration, our analysis of the JA focuses specifically on New Brunswick's Acadian youths. The questionnaire results provide a brief description of the socio-linguistic and demographic characteristics of the youths studied. Of the three games, New Brunswick participants in the $2001 \mathrm{JA}$ finals were the youngest and they manifested the strongest and least varied relationships to French language (See Table 1 and 2). These athletes at the JA can be roughly separated in three groups on the basis of their experience of francophoneness:

1. close to 80 percent of them shared French as first language, came from francophone families, inherited Acadian, French Canadian or French heritage, and communicated mostly in French;

2. about15 percent declared having both French and English as a first language, came from linguistically mixed families and usually spoke both French and English; and

3. the last 5 percent were of English mother tongue, came from non-francophone or linguistically mixed families, and they predominantly used English. ${ }^{7}$

7. It should be noted that of the ten total JA participants who declared not having learned French or English as a first language, seven of them identified "franglais", "chiac" and "brayon" as their mother tongue which are terms that refer to a mix of both French and English. 
152 Canadian Journal of Sociology

Table 1. Questionnaire results - Demographic characteristics of Jeux de l'Acadie (JA), Jeux franco-ontariens (JFO) and Alberta Francophone Games (AFG) participants ${ }^{1}$

\begin{tabular}{|c|c|c|c|c|c|}
\hline & & $\begin{array}{c}J A-N B^{2} \\
2001 \\
n=615\end{array}$ & $\begin{array}{c}J F O \\
2001 \\
n=587\end{array}$ & $\begin{array}{c}A F G \\
1996 \\
n=144\end{array}$ & $\begin{array}{c}A F G \\
1997 \\
n=164\end{array}$ \\
\hline & & $\%$ & $\%$ & $\%$ & $\%$ \\
\hline \multirow[t]{6}{*}{ Age } & 10-12 years old & 32.2 & 0.2 & 22.6 & 8.5 \\
\hline & 13 years old & 34.5 & 0.3 & 27.0 & 25.0 \\
\hline & 14 years old & 20.3 & 10.3 & 24.1 & 26.2 \\
\hline & 15 years old & 9.4 & 26.1 & 16.8 & 23.2 \\
\hline & 16 years old & 3.4 & 28.0 & 5.1 & 11.6 \\
\hline & 17-20 years old & 0.2 & 35.1 & 4.3 & 5.5 \\
\hline \multirow[t]{2}{*}{ Place of birth } & In Canada & 99.2 & 96.3 & 99.0 & 100.0 \\
\hline & Outside Canada & 0.8 & 3.8 & 0.9 & 0.0 \\
\hline \multirow[t]{2}{*}{ Sex } & Female & 51.0 & 65.1 & 51.4 & 46.6 \\
\hline & Male & 49.0 & 34.9 & 48.6 & 53.4 \\
\hline \multirow[t]{6}{*}{ Ethnicity $^{3}$} & Acadian & 45.8 & - & - & - \\
\hline & French Canadian & 10.0 & 52.7 & - & - \\
\hline & French & 17.3 & 9.2 & - & - \\
\hline & Canadian & 15.5 & 5.3 & - & - \\
\hline & English (English Canadian) & 3.2 & 8.4 & - & - \\
\hline & Other & 8.1 & 24.5 & - & - \\
\hline
\end{tabular}

1. The total number of answers within each category is sometimes less than the value of $n$ since not all questionnaires were completely answered.

2. These JA results only includes the data for New Brunswick participants.

3. This question was not included in the questionnaires submitted to the AFG participants.

That only five New Brunswick participants were born outside of Canada, in addition to the fact that only eight percent of these teenagers used the category "other" to describe their ethnic heritage, attests to the mostly homogeneous cultural heritage and experiences of JA participants. ${ }^{8}$ These strong relationships to francophoneness can in large part be explained by the fact that francophones in New Brunswick represent over one third of the provincial population and benefit from the highest rate of linguistic continuity (92 percent) ${ }^{9}$ (Allaire, 1999). A second contributing factor to the higher use of French by New Brunswick youths is that participation in the Games is restricted to students from francophone schools.

8. Of the 107 ethnicities identified by all JA youths on the questionnaire, 34 refer to ethnicities associated to francophoneness in Canada, such as Brayonne, francophone, Franco-Canadian, Québécois and Franco-Ontarian, and 11 others to what could be considered Canadian or provincial identities.

9. The rate of linguistic continuity measures the proportion of francophones who communicate in French at home. 
Table 2. Questionnaire results - Linguistic characteristics of Jeux de l'Acadie (JA), Jeux francoontariens (JFO) and Alberta Francophone Games (AFG) participants ${ }^{1}$

\begin{tabular}{|c|c|c|c|c|c|}
\hline & & $\begin{array}{c}J A-N B^{2} \\
2001 \\
n=615\end{array}$ & $\begin{array}{c}J F O \\
2001 \\
n=587\end{array}$ & $\begin{array}{c}A F G \\
1996 \\
n=144\end{array}$ & $\begin{array}{c}A F G \\
1997 \\
n=164\end{array}$ \\
\hline & & $\%$ & $\%$ & $\%$ & $\%$ \\
\hline \multirow[t]{4}{*}{ First language } & French & 78.6 & 57.7 & 42.6 & 50.0 \\
\hline & English & 4.2 & 14.7 & 34.0 & 28.7 \\
\hline & French and English & 16.0 & 23.9 & 18.4 & 18.9 \\
\hline & Other & 1.1 & 3.6 & 4.3 & 2.4 \\
\hline \multirow{3}{*}{$\begin{array}{l}\text { Parents' first } \\
\text { language }\end{array}$} & French (both parents) & 80.7 & 57.0 & 49.3 & 52.1 \\
\hline & French (one parent) & 17.8 & 31.7 & 22.1 & 20.9 \\
\hline & English/other (both parents) & 1.5 & 11.3 & 28.7 & 27.0 \\
\hline \multirow[t]{4}{*}{ Home languages } & French (only and mostly) & 80.6 & 52.3 & 24.8 & 28.2 \\
\hline & English (only and mostly) & 6.1 & 31.7 & 36.9 & 38.7 \\
\hline & French and English (equally) & 10.3 & 13.3 & 34.8 & 31.3 \\
\hline & Other & 3.0 & 2.7 & 3.5 & 1.8 \\
\hline \multirow{4}{*}{$\begin{array}{l}\text { Language with } \\
\text { friends }\end{array}$} & French (only and mostly) & 76.6 & 32.2 & 5.9 & 8.1 \\
\hline & English (only and mostly) & 6.2 & 45.8 & 60.7 & 50.0 \\
\hline & French and English (equally) & 14.1 & 21.3 & 32.6 & 42.0 \\
\hline & Other & 3.0 & 0.7 & 0.7 & 0.0 \\
\hline \multirow{4}{*}{$\begin{array}{l}\text { Language of } \\
\text { education }{ }^{2}\end{array}$} & French & 100.0 & 100.0 & 52.9 & 56.7 \\
\hline & French immersion & - & - & 35.5 & 34.1 \\
\hline & English & - & - & 1.4 & 3.0 \\
\hline & French and English & - & - & 10.1 & 6.1 \\
\hline
\end{tabular}

\section{Ontario and the Jeux franco-ontariens}

Franco-Ontarians constitute the largest francophone community in Canada (outside Quebec) with a population of 509,265. Ontario, however, is Canada's most populous province, and francophones account for only 4.5 percent of its total population (Statistics Canada, 2002). Francophone Ontario is less concentrated than New Brunswick's Acadia, and it accounts for a much smaller proportion of the provincial population. Nonetheless, Ontario francophones are not dispersed evenly: there are longstanding and well established concentrations of francophones, the most important of which are in the north and east of the province. Toronto also counts a significant number of francophones, but the character of that "concentration" is rather different: by and large, Toronto's francophones are recent arrivals and are spread widely across the great metropolis. There are also historic francophone communities 
in the southwestern part of Ontario, but their numbers and relative weight are smaller.

As in New Brunswick's Acadia, there exist in Ontario strong institutional educational, community and religious networks. The Association canadiennefrançaise de l'Ontario (ACFO) was founded in $1910^{10}$ (Commissioner of official languages, 2001); Le Droit, a daily newspaper, was created in 1913. There are community associations and activities in literature, theatre, music, visual arts; a provincially funded, public French-language television station, TFO, along with approximately twelve weekly newspapers, community radio stations and private radio stations (Allaire, 1999; Commissioner of Official Languages, 1998).

Public French grade schools have existed since 1927, but high schools did not exist until 1968. Paradoxically, perhaps, the Université d'Ottawa was created as early as 1848 , as a bilingual university. In the 1960s, other bilingual universities were founded: Laurentian and Glendon College. According to the Commissioner of Official Languages (1998), in 1997 there were about ten postsecondary institutions (universities and colleges) providing French language programs to about 20,000 francophone students. In January 1997, a network of French-language school boards was created, covering the entire province and "repatriating" students from French-language programs offered by predominantly anglophone school boards (Commissioner of Official Languages, 1998). Francophone schools attract 64.1 percent of the target population and mixed schools ${ }^{11}$ attract another 1.3 percent (Martel, 2001).

The former Ontario francophone secondary school student federation, now reinvented as a larger francophone youth association, the Fédération de la jeunesse franco-ontarienne (FESFO) ${ }^{12}$ established the JFO in 1994 and purposefully moved away from the dominant Olympic sport model reproduced at other francophones games in Canada. These annual games are a successful multidisciplinary event, closer to a youth festival than to a sport tournament. Participants at the JFO are not only the school "jocks" but also the school clowns, artists, musicians, singers and the leaders involved in school council. Like the JA, the JFO are fairly large, attracting up to eight hundred 14- to 18year old participants and volunteers, and are limited to teenagers enrolled in francophone schools.

10. Although the ACFO's future has recently been threatened by financial problems, community consultations held in the summer of 2004 have confirmed that francophones wish to preserve a strong provincial association that provides political leadership.

11. A mixed school offers a francophone program as well as a French immersion program or a regular English language program.

12. Originally called Fédération des élèves du secondaire franco-ontarien, it adopted the name Fédération de la jeunesse franco-ontarienne in April 1994 but maintained the acronym FESFO. 
Of the three games, the JFO attract the older and most culturally diverse teenagers. The proportion of participants born outside Canada (3.8 percent) is quite small, yet it is still higher than at the AFG and at the JA. In addition, the variety of countries of birth is greater and the list of declared first languages and home languages is correspondingly varied. As opposed to the JA where most of the participants used the category "other language" to indicate a mix of French and English as a distinct language, only one participant at the JFO used that category to specify a home language of franglais. The most telling measure of the multicultural character of these youths is that approximately a quarter of the participants claimed a variety of ethnic heritages, sometimes more than one, most of them not obviously associated to francophoneness.

The results presented in Table 2 reveal that JFO participants from linguistically mixed families where one parent was of French mother tongue were more numerous ( 31.7 percent) than at the other two games. The proportion of youths with French as a first language, from French or French Canadian ethnicity, from francophone families and who predominantly communicated in French at home and with friends was approximately sixty percent, which is the middle point between the comparable groups at the JA and at the AFG (See Table 1 and 2). The rate of linguistic continuity of Ontario francophone youth, at 63 percent (Allaire, 1999), is also half-way between those of New Brunswick and Alberta. The analysis of the questionnaires reveals that the proportion of youths who declare having both French and English as mother tongues is quite similar for the three games. What varies is the proportion of those who seem to have closer ties to French, which is higher at the JA, while those who have closer relationships with English are more numerous at the AFG.

\section{Alberta and the Alberta Francophone Games $(A F G)^{13}$}

Francophones were present in Alberta from the first days of Euro-Canadian colonisation of the prairies. Until the second third of the nineteenth century, they were the majority group among non-indigenous people in the territory, which was to acquire provincial status in 1905. From the late nineteenth century on, massive immigration and discriminatory policies, particularly in schooling, reduced the francophone community to a small minority $(2.1$ percent) of the provincial population (Statistics Canada, 2002). There were, and are, relative concentrations, however, in the northwest as well as in and around the provincial capital, Edmonton.

In Alberta, as in Ontario, the francophone community has been constructed

13. The organizers of the Alberta Francophone Games (AFG) have officially translated the name of their Games. Thus organizers use the English version of the name in all English language documentation. Conversely, the organizers of the JA and the JFO have not officially translated the name of their Games and use the French language name strategically in all communication. 
and conceived historically on the basis of French Canadian ethnicity (JuteauLee and Lapointe, 1983; Trottier, Allaire and Munro, 1980; Thériault, 1994, 1999). Today, the once dominant cultural discourse still has wide currency (Dallaire and Denis, 2000), but it has been contested by the integration of French speakers of other ethnic origins and it is under pressure from the legally established linguistic rights regime ${ }^{14}$ that reinvents francophone communities as linguistic communities (Bernard, 1998; Cardinal, 1997).

Being few in numbers at 62,240 (Statistics Canada, 2002) and with limited geographical concentration, Alberta's francophones have developed an institutional network that lacks the reach and depth of those in Ontario and Acadia/ New Brunswick. There is a provincial association, the Association canadiennefrançaise de l'Alberta (ACFA), a weekly newspaper, Le Franco, and the radiotelevision presence of Radio-Canada, a community radio station in the north.

As a result of the Canadian Charter of Rights and Freedoms in 1985 and of subsequent judicial decisions, Alberta francophones (along with those of other provinces) gained control of their elementary and secondary schools and, eventually, school boards. Between 1986 and 1997, the number of francophone schools increased from two to seventeen and the number of students in these schools from 526 to 2246 . But in 1996, only 7.9 percent of the target population of students was studying in francophone schools, while 6.7 percent of students who have the right to an education in French were enrolled in the French-language programs of mixed schools. Thus, more than 85 percent of students who have a Charter right to schooling in French are in the schools of the anglophone majority (Martel, 2001). No autonomous postsecondary institution exists, but the University of Alberta's Faculté Saint-Jean is an important component of the francophone community, with approximately five hundred students.

In 1997, several important institutions were inaugurated: la Cité des Rocheuses in Calgary (which houses a primary and secondary school, a theatre, a daycare centre, the local francophone newspaper and other associations),$^{15}$ la Cité francophone in Edmonton (housing a theatre, the offices of the provincial francophone newspaper and several associations, a daycare centre, a medical clinic and a bookstore) and the Centre scolaire et communautaire in Fort McMurray, also housing a school, a daycare centre and the offices of the local francophone association (Commissioner of Official Languages, 1998).

In light of the success of the Jeux de l'Acadie in the maritime provinces, the annual Alberta Francophone Games (AFG) were created in 1992 to promote

14. The Canadian Charter of Rights and Freedoms and the Official Languages Act are two examples of federal laws that govern linguistic rights in Canada with regards to education and federal government services (Government of Canada, 1982, 1988).

15. Since December 2003, the newspaper and some francophone associations have moved to a new Édifice le ROCC in the downtown area. 
French language and culture among 12 to 18 year-old youths. From 1992 to $2003,{ }^{16}$ this annual multi-sport attempt at replicating the JA attracted between 150 and 275 teenagers for a "French" weekend, where sport is basically meant to be the principal medium through which the language is lived. The AFG have only one criterion to select prospective participants: priority is given to the athlete who will demonstrate willingness to speak French throughout the weekend.

The AFG attracted the smallest proportion, only approximately half, of French mother-tongue teenagers and the highest proportion, approximately 30 percent, of English/non-French mother tongue participants (See Table 2). Another fifth of the participants claimed both French and English as first languages. Correspondingly, both parents of half of the participants spoke French as mother tongue, a fifth of the participants came from linguistically mixed families, and neither of the parents of the remaining third had French as a first language. Thus, two thirds of the participants possibly learned French at home while one third learned it as a second language, presumably at school. Participants had different connections to French in terms of mother tongue and family environment, and they also came from schools where the French language held a different status. In fact, participants are recruited in Alberta's francophone schools, French immersion schools ${ }^{17}$ and mixed schools. Thus, the AFG evidently gather a group of youths for whom French emanates from the family environment, but they also attracted another group for whom French was a language strictly associated with school. Between these two extremes were other participants for whom the practice of French took on various meanings - ie, was grounded in different social contexts. It is the combination of the particularly weak socio-demographic situation of this francophone community and the organizers' desire to stage "big" Games (see Dallaire, $2003 \mathrm{~b}$ ), that produced the AFG's recruitment of participants among nonfrancophone schools, a practice opposite that in Acadia/New Brunswick and Ontario.

\section{Doing the francophone, more or less: The asymmetrical hybridity of young francophones}

Hybridization unquestionably shaped the francophoneness of youths at the three games. They reproduced themselves as "not just francophones," but as

16. A teachers' strike led to the cancellation of the May 2002 AFG. However, smaller games with a little over 30 participants were held later in the summer in the context of the 2002 Fête francoalbertaine. In contrast, the 2004 AFG attracted a record of 370 teenagers, including a guest delegation from the North West Territories.

17. French immersion schools provide educational programs that progressively teach French language to non-French-speaking students and eventually teach the entire curriculum in French. 
158 Canadian Journal of Sociology

anglophones as well (Dallaire, 2003a). However, the configuration of their hybridity and the significance of francophoneness in their sense of self varied between individual youths, between groups (as defined by their ties to French language), and between the three Games.

The performance of francophoneness sets AFG participants apart from JA youths. An important proportion of JFO youths may have been closer to AFG youths in terms of their linguistic practices, but they produced a distinct francophone identity that emphasized the importance of performing in French and committing to the expansion of francophoneness (Dallaire, 2004). AFG youths' spontaneous use of English to speak with one another was a discursive practice that contributed to the construction of their distinct hybrid identity, where francophoneness was performed as a weaker component than their anglophoneness. Indeed, one linguistic characteristic shared among most of the Alberta youths was their frequent use of English, or a combination of French and English, when conversing with friends (See Table 2). Their shift to English was automatic: "It is just a habit to switch to English.", ${ }^{18,19}$ (AFG/E4, 1997). Even participants who had French as a first language and were from francophone families found it difficult and "unnatural" to communicate in French, let alone to speak it spontaneously and constantly:

- It is difficult to not speak English. Because we speak English all the time.

- Yes. It is our environment because we speak English all the time.

- Speaking French is weird.

[...]

- Yes, it is natural to speak English. ${ }^{20}$ (AFG/E3, 1997).

Like Bernard (1998), we did observe that francophone youths in Alberta wished to retain their francophone language and culture and wanted to pass it on to their children. It was, in fact, clearly expressed in an AFG drawing: "I hope to preserve my language to teach it to my children. My language is IMPORTANT $^{21}$ to me. Thank you." ${ }^{22}$ (\#26, AFG/E8, 1997). ${ }^{23}$ The paradox,

18. We have translated all quotes from French to English and italicized the words youths had originally used in English during the interviews or on the drawings.

19. "C'est juste une habitude de switcher en anglais."

20. “- C'est dure de ne pas parler anglais. Parce qu'on parle anglais tout le temps.

21. Capital letters in the original drawing.

22. "J'espère garder ma langue pour enfin la montrer à mes enfants. Ma langue est IMPORTANTE pour moi. Merci."

23. The fact that at fifteen years old, this young francophone was already consciously articulating the desire to transmit her language to her future children points to the problematic character of her francophoneness. If her language had not been weakened or threatened, whether her own fluency in French or the political and social status of French in Alberta and Canada, she would arguably not have thought about it. That her children would have spoken French would have been a given. 
Bernard (1998) noted, was that minority youths primarily lived their life in English, which was certainly the case for AFG youths, compared to youths at the JFO and at the JA. In fact, interviews confirmed questionnaire results concerning youths' linguistic practices at home and with friends. English was the language of choice for AFG participants' leisure activities. They reported consuming mostly English language popular culture through radio, television and films, their overall knowledge or awareness of French language popular culture being minimal. In short, francophone discourses were not powerful enough to discipline AFG participants to perform as francophones. Youths at the 1996 and 1997 Games manifested the highest rate of affiliation to anglophoneness and the lowest rate of francophone identification and practices. They did not all think of themselves as "true" francophones, but they could all speak some French and, as a result of this, they at least partly identified with francophoneness. In participating in the Games, they were at the minimum manifesting an appreciation for the French language, if not for francophone culture. They had, obviously, agreed to participate in a francophone event.

As did AFG participants, JFO youths mostly preferred English language popular culture. They were aware of and enjoyed, however, certain FrancoOntarian or mainstream francophone cultural products and artists. JFO youths also combined French and English in their conversations, yet interviews and questionnaires show that, compared to AFG participants, they were more likely to speak mostly French and use some English vocabulary.

S: Yes. You speak French all the time, but it's just sometimes a couple of English expressions. That is your way of speaking English. When you say a few expressions or something like that. Most of the time, people speak all in French, except for a couple of exceptions.

N: That is Franco-Ontarian French, anyway. ${ }^{24}$ (JFO/E/K20\#3, 2001)

$\mathrm{J}$ : Well I know that I will almost always speak French because I am more comfortable in French. But it is certain that some English expressions will come out and English words because, I mean, we live in a totally bilingual culture. (...)

R: I already always speak French, so ... I even have difficulty with English. But even then, I have words that come out in English. It is pretty much the Franco-Ontarian language. Some expressions, like J was saying, are part of our vocabulary. ${ }^{25}$ (JFO/E/K18\#1, 2001)

24. 'S : Oui. Tu parles français tout le temps, mais c'est juste des fois une couple d'expressions en français. C'est ça ta manière que tu parles en anglais. Quand tu dis une expression ou quelque chose comme ça. La plupart du temps, le monde parle tout en français, except pour une couple d'exceptions.

$\mathrm{N}$ : Ça, c'est du français franco-ontarien anyway."

25. "J : Bien je sais que moi je vais pas mal toujours parler en français parce que je me sens beaucoup plus confortable à parler en français. Mais c'est sûr qu'il y a bien des expressions anglaises qui vont sortir puis des mots anglais parce que, je veux dire, on vit dans une culture totalement bilingue. (...) 
Although less frequently than at the AFG, some JA and a few more JFO participants also did answer that they occasionally had to make an effort to communicate in French rather than in English at the games. What is most notable here is the apparent disparity between what JA youths said in interviews about how they viewed their linguistic practices as mixed, and what emerged from the questionnaire, interviews and fieldwork in terms of their ease and incidence in speaking French. JA youths perceived themselves as bilingual and as actively speaking in both French and English, but at the games, they certainly engaged in practices that produced them as francophones. Fieldwork revealed that they did occasionally use an expression or a word in English, but French dominated practically all exchanges observed. Communicating in French was a given throughout the weekend. Furthermore, JA youths were the most likely to communicate in French during their leisure activities and to enjoy mainstream French language popular culture, and specifically what they referred to as Acadian parties, music and songs.

Both JFO and JA youths recognized that some English was perhaps spoken among participants during the games, but they expected that an effort would be made to speak French most of the time. They acknowledged that the point of the event was to celebrate francophoneness and particularly the French language and they felt that it was important to speak French during the weekend. JFO youths would even remind their peers to communicate in French if they overheard them conversing in English. In contrast, many AFG participants evidently did not think that it was necessary to speak French regularly to identify as a francophone. They acknowledged the requirement to speak French throughout the weekend and they agreed, in principle, with the purpose of the Games to promote francophoneness. However, showing a positive attitude towards French and an effort to speak French appeared to be more important to them than actually performing in French. In addition, questionnaire results showed that they primarily attended to have fun and to play sports. In most cases, the francophoneness of the event was incidental to their motivation for participation.

The varying stability and specificity of the francophone discursive production and its impact on the performance of, and affiliation to, francophoneness certainly merits closer examination. Indeed the analysis of the articulation of francophone discourses at the three games shows that the discursive production of francophoneness was more stable at the JA and the JFO than at the AFG. A first, obvious indication of this is the way in which youths self-

$\mathrm{R}$ : Moi, je parle déjà toujours en français, alors ... J'ai même de la misère avec mon anglais. Mais encore là, j'ai des mots qui sortent en anglais. C'est le langage franco-ontarien pas mal. Certaines expressions, comme J disait, qui font partie de notre vocabulaire." 
Asymmetrical Hybridities: Youths at Francophone Games in Canada 161

identified. Youths participating in the three games chose different labels to best describe their sense of self, thereby expressing differences between the three games in the intensity of teenagers' explicit attachment to francophoneness. The most frequent choice of JA and JFO participants is the identity associated with their respective francophone community (Franco-Ontarian and Acadian), while the most common identity among AFG participants is "Canadian" (See Table 3). And when the various answers that can be explicitly associated to francophoneness are combined, we get 59 percent at the JA, 55 percent at the JFO and only 39 percent to 45 percent at the two AFGs (1997 and 1996) who identify first as francophones.

On the other hand, as we have shown elsewhere (Dallaire, 2003a), when minority francophone youths identify as "Canadian" (17 percent, 18 percent and 47 percent and 35 percent respectively at the JA, JFO, AFG), they are indicating that they are "more than just francophone", but rather both francophone and anglophone. They explain their use of "Canadian" to emphasize the fact that Canada has two official languages, French and English, and to express the idea that Canadians speak both French and English. ${ }^{26}$ In their most frequent choice of identity, then, AFG participants denote their hybridity, while JA and FJO youths focus on their francophoneness.

Table 3. Questionnaire results to the question: Main identity for youths at the Jeux de l'Acadie (JA, Alberta Francophone Games (AFG) and Jeux franco-ontariens (JFO) ${ }^{1}$

\begin{tabular}{lcccc} 
& $J A-N B^{2}$ & $J F O$ & $A F G$ & $A F G$ \\
& 2001 & 2001 & 1996 & 1997 \\
& $n=815$ & $n=587$ & $n=144$ & $n=164$ \\
& $\%$ & $\%$ & $\%$ & $\%$ \\
Franco-Ontarian / Acadian / & & & & \\
$\quad$ Franco-Albertan & 40.7 & 37.6 & 7.9 & 13.7 \\
Bilingual & 14.9 & 19.0 & - & 16.8 \\
Canadian & 16.8 & 18.3 & 46.5 & 34.8 \\
French Canadian & 4.6 & 10.5 & 23.6 & 27.3 \\
Francophone & 8.1 & 6.6 & 7.9 & 4.3 \\
Bilingual Canadian & 2.5 & 3.0 & - & - \\
Franco-Canadian & 5.8 & - & - & - \\
Other & 6.5 & 5.1 & 9.5 & 3.1 \\
Francophile & - & - & 4.7 & 0.0 \\
\hline
\end{tabular}

1. This category provides participant answers to the question: Which term identifies you best? The results provided here only include the term respondents identified as the most important. Answers that included more than one term without placing them in order of priority are excluded from this analysis.

26. Most Canadians do not, as a matter of fact, speak both languages. Only 17.7 percent of Canadians can conduct a conversation in both official languages (Statistics Canada, 2002). 
It should be noted, however, that the overall questionnaire results to the question "What term identifies you best?" clearly show that there is no consensus among participants: not one label was chosen by at least half the participants at any of the three games. Indeed, questionnaire results reveal that minority francophone youths construct their identity variously, from different choices made available to them in discourses about francophone and Canadian identity: no hegemonic label imposes itself. For instance, at the JA, the "Acadian" specificity was a given and the cultural discourse producing an ethnic Acadian identity was prevalent. The JA were typified by a strong Acadian ethnic identity exemplified in the profusion of Acadian flags, symbols, colors, traditions, music and dance throughout the weekend and also illustrated in youths drawings. There was no mistaking that these were "Acadian" games. Thus, 82 percent of the 181 JA drawings mentioned the "Acadian" character of the identity and/or community being reproduced at the games.

The JFO were instead marked by the fervent articulation of a linguistic discourse producing a multicultural and inclusive francophone identity based on one's commitment to living in French (Dallaire, 2004). The overwhelming incidence of the linguistic criteria, combined with a decisive integration of all dedicated French speakers, regardless of their mother tongue and ethnic or racial origins, contributed to creating a stable discursive environment throughout the weekend. Youths were aware that other groups and organizations promoted different versions of what a francophone is, but they sided with the FESFO vision of multiculturalism and inclusion in creating an intense, discursively stable, youthful and inviting francophone environment.

\section{Conclusion}

Francophone and anglophone identities in Canada are not produced from essential cultures, nor are they static. They change and shift continually. What hybridity implies, in addition to recognition of this dynamic, is a disruption and integration of these two identities that have been changing but distinct, and historically constructed as opposed. What is more, the hybrid cultural identities of minority francophone youths can be more complicated and complex in that they may integrate, in addition to francophoneness and anglophoneness, other cultural affiliations as well. Indeed, questionnaire results revealed that some teenagers declared various ethnic lineages. If we had asked about tastes in music, clothing, gaming, etc. — all of which make varying contributions toidentity - we would certainly have found considerable diversity. However, our analysis of the hybridity of these youths is purposefully limited to an examination of the manifestation of their francophoneness and anglophoneness. 
It is interesting to note that, from the point-of-view of participants, this focus on identities related to French and English languages is also, in part, a function of the research process itself: in their communication with us, participants primarily refer to related linguistic practices as core dimensions of their self-definition. This is not surprising, nor is it a methodological problem, since the purpose of francophone games is to provide a context where youths will live "in French" in order to reduce or prevent youths' linguistic transfer to the anglophone majority. French versus English linguistic practices are at the crux of the games, as they are in francophone minority identity discourses in Canada. In a sense, then, the focus of the research appears to the participants as a kind of extension of the games themselves.

Youths' agency, their active and conscious choices among possible subjectivities, is especially important in the context of francophone community building. Minority francophone identity is, to a fairly large extent, a choice. But it should be emphasized that as "free" subjects, youths can only choose among the discursive possibilities open to them. In the same way that particular circumstances limit young people's choices in Kathmandu to mediated views of Nepali identity (Liechty, 1995), young francophones' reproduction of hybrid identities in Canada occurs in a specific discursive environment that opens some possibilities at the same time that it restricts other alternatives. In this sense, choice is constrained. Nonetheless, there is choice rather than outright determination, as other work in this area has at least suggested (See, for instance, Landry and Allard, 1997). But what are those limitations and how can they be stretched? What brings young francophones to select or integrate some discourses rather than others and to produce particular configurations of hybridity that enhance or undermine their francophoneness? More research is needed into such questions. For instance, comparative research between francophone minority youths and young anglophones in Quebec would likely provide further insights into the discursive production of asymmetrical hybridities. Furthermore, comparisons with youths of immigrant parents in Quebec would be useful as well since Mimeault, LeGall and Simard (2002) observed that such youths also embody a mix of various cultural influences and insist on their dual affiliations with the minority and with the majority.

This paper has examined the manifestation of asymmetrical power relationships within hybridity as it is lived by teenagers in three francophone communities in Canada. The comparison of the affiliation and the performance of francophoneness among the participants at the three games illustrates that hybridity does not mean that francophoneness is equally, softly blended with anglophoneness. Indeed, as Pieterse (1995) stresses, 
164 Canadian Journal of Sociology

Relations of power are inscribed and reproduced within $^{27}$ hybridity for wherever we look closely enough we find the traces of asymmetry in culture, place, descent. Hence, hybridity raises the question of the terms of mixture, the conditions of mixing and mélange. At the same time it's important to note the ways in which hegemony is not merely reproduced but refigured ${ }^{28}$ in the process of hybridization. (p. 57)

Hybrid individuals do not necessarily perform mixed cultural activities and practices in equal measures (Pieterse, 1995). In this study, as in Noble et al.'s (1999) research, even youths who lived ethnicity as if it were an essential identity did not all manifest the same intensity of ethnic identification, thus leading to different hybrid configurations. However, as Laflamme (Laflamme, 2001; Laflamme and Berger, 1991/1992) and Gérin-Lajoie (2003) have argued in the case of francophone youths and as Lie (2000) has observed in the case of youths from the former Yugoslavia living in Norway, bilingualism and biculturalism do not inevitably lead to the assimilation of minority youths. It is indeed possible to maintain a significant level of competence in the minority community and first language while using a second language for communication in majority settings.

\section{References}

\section{Academic sources}

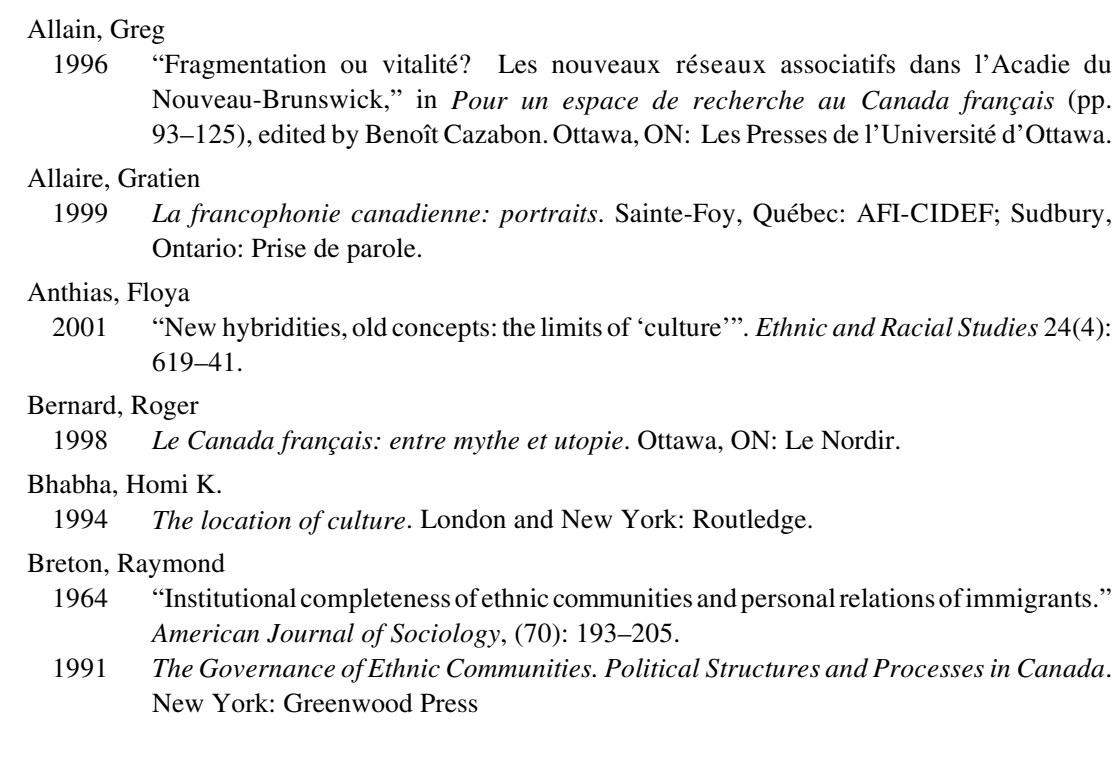

27. Emphasized in the original.

28. Emphasized in the original. 
Asymmetrical Hybridities: Youths at Francophone Games in Canada 165

Butcher, Melissa and Thomas, Mandy

2002 "Generate: Youth Culture and Migration Heritage in Western Sydney." Paper presented at the International Sociological Association XVth ISA World Congress of Sociology, Brisbane, Australia.

Butler, Judith

1990 Gender trouble. Feminism and the subversion of identity. New York and London: Routledge

1991 "Imitation and Gender Insubordination," in Inside/out: lesbian theories, gay theories (pp.13-31), edited by Diana Fuss. New York and London: Routledge.

1993 Bodies that matter: on the discursive limits of "sex." New York: Routledge.

Cardinal, Linda

1997 L'engagement de la pensée. Écrire en milieu minoritaire francophone au Canada. Ottawa, ON: Le Nordir, 1997.

Commissioner of Official Languages

1998 Annual Report. 1997. Ottawa, ON: Office of the Commissioner of Official Languages, Government of Canada.

2000 Annual Report. 1999-2000. Ottawa, ON: Office of the Commissioner of Official Languages, Government of Canada.

2001 Our Official Languages: As a Century Ends and a Millenium Begins. Ottawa, ON: Office of the Commissioner of Official Languages, Government of Canada,

Dallaire, Christine

1999 The Alberta Francophone Games: A Question of Identity. Unpublished doctoral dissertation, University of Alberta, Edmonton, Alberta.

2001 "La communauté francophone en Alberta: ce que les jeunes en pensent" in Communautés francophones. Espaces d'altérités (pp. 27-57), edited by Paul Dubé and Pamela Sing. Edmonton, AB: Institut de recherche de la Faculté Saint-Jean.

2003a “'Not Just Francophones': The Hybridity of Minority Francophone Youths in Canada," International Journal of Canadian Studies, (28): 163-199.

$2003 \mathrm{~b}$ "Sport's Impact on the Francophoneness of the Alberta Francophone Games," Ethnologies 25(2): 33-58.

2004 "Fiers de qui nous sommes ... Nous sommes FRANCOPHONES! L'identité des jeunes aux Jeux franco-ontariens," Francophonies d'Amérique, (18): 127-147.

Dallaire, Christine and Denis, Claude

2000 "'If you don't speak French, you're out': Don Cherry, the Alberta Francophone Games, and the Discursive Construction of Canada's Francophones," Canadian Journal of Sociology 25, (4): 415-40.

Dallaire, Christine and Roma, Josianne

2003 "Entre la langue et la culture, la reproduction de l'identité francophone des jeunes en milieu minoritaire au Canada. Bilan des recherches," in Actes du colloque pancanadien sur la recherche en éducation en milieu francophone minoritaire : Bilan et prospectives (pp. 30-46), edited by Réal Allard. Moncton, NB: Association canadienne d'éducation de langue française (ACELF) and Centre de recherche et de développementen éducation (CRDE), Université de Moncton.

Freidman, Jonathan

1997 "Global Crises, the Struggle for Cultural Identity and Intellectual Porkbarrelling: Cosmopolitans versus Locals, Ethnics and Nationals in an era of De-hegemonisation," in Debating Cultural Hybridity: Multi-cultural Identities and the Politics of Anti-Racism (pp. 70-89), edited by Prina Werbner and Tariq Modood. London \& New Jersey: Zed Books. 


\section{Canadian Journal of Sociology}

1999 "The hybridization of roots and the abhorrence of the bush," in Spaces of Culture: City, Nation, World (pp. 230-256), edited by Mike Featherstone and Scott Lash. London, UK: Sage.

Garcìa Cancline, Nestor

1995 Hybrid Cultures: Strategies for Entering and Leaving Modernity. [Culturas hibridas. Translated by Chiappari, Christopher L. and Lopez, Sylvia L., 1989.] Minneapolis, MN: University of Minnesota Press.

Gérin-Lajoie, Diane

2003 Parcours identitaires de jeunes francophones en milieu minoritaire. Sudbury, ON: Prise de Parole.

Government of Canada

1982 Canadian Charter of Rights and Freedoms. Ottawa, ON: Department of Justice, Canada

1988 Official Languages Act. Ottawa, ON: Secretary of State and Department of Justice, Canada, 1988.

Juteau-Lee, Danielle and Jean Lapointe

1983 "From French Canadians to Franco-Ontarians and Ontarois: New Boundaries, New Identities," in Two nations, many cultures: Ethnic groups in Canada (pp. 173-186), edited by Jean Leonard Elliot. 2nd ed. Scarborough, ON: Prentice Hall.

Kraidy, Marwan M.

1999 "The global, the local, and the hybrid: A native ethnography of glocalization." Cultural Studies in Mass Communication, (16): 456-76.

Laflamme, Simon

2001 "Alternance linguistique et postmodernité: le cas des jeunes francophones en contexte minoritaire." Francophonies d'Amérique, (12) :105-12.

Laflamme, Simon and Berger, Jacques

1991/ "Autre considération sur le rapport entre la compétence linguistique et l'environnement

1992 social." Revue du Nouvel-Ontario, (13/14): 133-54.

Landry, Rodrigue and Allard, Réal

1997 "L'exogamie et le maintien de deux langues et de deux cultures: le rôle de la francité familioscolaire." Revue des sciences de l'éducation 23(3): 561-92.

LeBlanc, Phyllis, E.

1999 "Les grandes périodes de l'histoire de l'Acadie," in Francophonies minoritaires au Canada: L'état des lieux (pp.131-144), edited by J.Yvon Thériault. Moncton, NB: Les Éditions d'Acadie

Lie, Branka

2000 "Slavic and Norwegian Language and Culture in Contact: The Influence of the Norwegian Language and Culture on Immigrant Youth from the Fromer Yugoslavia," Migracijske Teme 16(1-2): 47-64.

Liechty, Mark

1995 "Youth and modernity in Kathmandu, Nepal," in Youth Cultures: A Cross-Cultural Perspective (pp. 166-201), edited by Vered Amit-Talai and Helena Wulff. London and New York: Routledge,

Mimeault, Isabelle, LeGall, Josianne and Simard, Myriam

2002 "Identités des jeunes régionaux de parents immigrés au Québec: métissage et ouverture sur le monde," Cahiers de Recherche Sociologique 36: 185-215.

Meerwald, Agnes May Lin

2001 "Chinese at the crossroads." European Journal of Cultural Studies 4(4): 387-404. 
Asymmetrical Hybridities: Youths at Francophone Games in Canada 167

Noble, Greg, Poynting, Scott and Tabar, Paul

1999 "Youth, ethnicity and the mapping of identities: Strategic essentialism and strategic hybridity among male Arabic-speaking youth in South-Western Sydney." Culturall Plural 7(1): 29-44.

Papastergiadis, Nikos

2000 The turbulence of migration: globalization, deterritorialization, and hybridity. Cambridge, UK: Polity Press; Malden, Mass: Blackwell, 2000.

Pieterse, Jan Nederveen

1995 "Globalisation as Hybridisation," in Global Modernities (pp. 45-68), edited by Mike Featherstone, Scott Lash and Robertson, Roland. London, UK: Sage.

1997 "Multiculturalism and Museums: Discourse about Others in the Age of Globalization." Theory Culture \& Society 14(4): 123-46.

2001 "Hybridity, So What? The Anti-hybridity Backlash and the Riddles of Recognition." Theory, Culture \& Society 18(2): 219-45.

Romberg, Raquel

1996 "Saints in the Barrio: Shifting, hybrid, and biocultural practices in a Puerto Rican community," Multicultural Review 5(2): 16-25.

Ross, Sally

2001 Les écoles acadiennes en Nouvelle-Écosse: 1758-2000. Moncton, NB: Centre d'études acadiennes, Université de Moncton.

Slabbert, Sarah \& Finlayson, Rosalie

2000 "'I'm a cleva!": The linguistic makeup of identity in a South African urban environment." International Journal of the Sociology of Language, (144): 119-135.

Statistics Canada

20022001 Census: Analysis series. Profile of languages in Canada: English, French and many others. Data released on December 10,2002. Catalogue no.96F0030XIE2001005. Ottawa, ON: Minister of Industry.

Thériault, Joseph Yvon

1994 "Entre la nation et l'ethnie. Sociologie, société et communautés minoritaires francophones." Sociologie et sociétés 26(1): 15-32.

1999 Francophonies minoritaires au Canada : L'état des lieux. (Editor) Moncton, NB: Les Éditions d'Acadie.

Trottier, Alice, Munroe, Kenneth F. and Allaire, Gratien

1980 Aspects du passé franco-albertain. Edmonton, AB: Le Salon d'histoire de la francophonie albertaine.

Young, Robert J.C.

1995 Colonial Desire. Hybridity in Theory, Culture and Race. London and New York: Routledge.

Interviews and documents

Alberta Francophone Games (AFG)/E3.

1997 Third participant interview with six girls from the Peace River region, May 17.

Alberta Francophone Games (AFG)/E4.

1997 Fourth participant interview with two boys and 3 girls from Fort McMurray (two) and Edmonton (three), May 17.

Alberta Francophone Games (AFG)/E8.

1997 Eighth participant interview with two boys and one girl from the Centralta region, May 19. 
168 Canadian Journal of Sociology

Jeux franco-ontariens (JFO)/E/K18\#1

2001 Interview with two girls on the volunteer team, May 18.

Jeux franco-ontariens (JFO)/E/K20\#3

2001 Interview with four boys in sports, May 20.

Jeux de l'Acadie

2002 “Société des Jeux de l’Acadie. Information générale : Historique.” Official web site of the Jeux de l'Acadie [http://www.jeuxdelacadie.org/info_gen/historique.html] (Access date: May 25 2002) 
Copyright of Canadian Journal of Sociology is the property of Canadian Journal of Sociology and its content may not be copied or emailed to multiple sites or posted to a listserv without the copyright holder's express written permission. However, users may print, download, or email articles for individual use. 